\title{
Generalised uridine diphosphate galactose-4-epimerase deficiency
}

\author{
J H Walter, R E P Roberts, G T N Besley, J E Wraith, M A Cleary, J B Holton, R MacFaul
}

Willink Biochemical Genetics Unit, Royal Manchester Children's Hospital, Pendlebury, Manchester M27 4HA, UK

$\mathrm{J}$ H Walter

R E P Roberts

G T N Besley

JE Wraith

M A Cleary

Department of Child Health, Royal Hospital for Sick Children,

Bristol BS1 5PZ, UK J B Holton

Pinderfields General Hospital, Wakefield, West Yorkshire WF1

4DG, UK

R MacFaul

Correspondence to:

Dr Walter.

email: john@

jhwalter.demon.co.uk

Accepted 11 November 1998

Table 1 Patients'details

\begin{abstract}
The generalised form of epimerase deficiency galactosaemia has been described in only two children from unrelated families. Their progress is reported and three other affected children from these families are described. The initial presentation was similar to classic galactosaemia. Despite treatment all have shown poor growth and moderate learning difficulties. Three have sensorineural deafness and four have pronounced dysmorphic features. The two older female patients have normal pubertal development.

(Arch Dis Child 1999;80:374-376)
\end{abstract}

Keywords: UDP galactose-4-epimerase deficiency; galactosaemia; transferrin isoelectric focusing

Galactosaemia is caused by inherited deficiencies in one of three enzymes involved in the metabolism of galactose: galactose-1phosphate uridyltransferase (GALT), galactokinase (GALK), and uridine diphosphate galactose-4-epimerase (GALE). GALE deficiency confined to red cells is benign. A generalised form has only been reported previously in two patients from unrelated families. ${ }^{1-3} \mathrm{We}$ report the progress of these children and describe three further cases from these two families.

\section{Case reports}

Both families are of Asian origin and highly consanguineous but are not known to be related one to the other. Details of the children's clinical presentation, investigations, and progress are given in table 1. All patients had raised concentrations of galactose-1phosphate (gal-1-P) at diagnosis, normal GALT, but undetectable GALE activity in red cells, confirming the diagnosis of GALE deficiency (see table 1 for details). The diagnosis of generalised, rather than peripheral, deficiency was established by the lack of detectable enzyme in cultured skin fibroblasts from patients 1 and 3 and in cultured amniocytes from patient 2 ; the same diagnosis was assumed for patients 4 and 5 .

All children were born at term following uneventful pregnancies. The index cases for each family (patients 1 and 3) presented with a clinical illness similar to that seen in classic galactosaemia (GALT deficiency) with poor feeding, weight loss, and evidence of liver and renal tubular disease. These were corrected by

\begin{tabular}{|c|c|c|c|c|c|c|}
\hline & $\begin{array}{l}\text { Year of } \\
\text { birth }\end{array}$ & $\begin{array}{l}\text { Newborn } \\
\text { presentation }\end{array}$ & Initial investigations & GALE activity & Dysmorphic features & Progress \\
\hline \multicolumn{7}{|l|}{ Pedigree $A$} \\
\hline $\begin{array}{l}\text { Patient } 1 \\
\quad \text { (female) }\end{array}$ & 1980 & $\begin{array}{l}\text { Jaundice, } \\
\text { weight loss, } \\
\text { hypotonia, } \\
\text { vomiting }\end{array}$ & $\begin{array}{l}\text { Urine positive for } \\
\text { reducing substances; } \\
\text { generalised } \\
\text { aminoaciduria; raised } \\
\text { liver transaminases; } \\
\text { gal-1-P } 305 \mu \mathrm{mol} / 1 \text {; } \\
\text { UDP gal } 105 \mu \mathrm{mol} / 1 \\
\text { (normal, } 0 \text { ) }\end{array}$ & $\begin{array}{l}\text { RBC: } 0.1 \mu \mathrm{mol} / \mathrm{ml} \text { red } \\
\text { cells } / \mathrm{h} \text { (controls, } \\
3.0-6.2 \text { ); fibroblasts: } \\
\text { undetectable; liver tissue: } \\
10 \% \text { of controls }\end{array}$ & $\begin{array}{l}\text { Facial dysmorphism with inner } \\
\text { canthus distance below third } \\
\text { centile, palpebral fissure length } \\
>97 \text { th centile, posteriorly } \\
\text { rotated ears and a short } \\
\text { philtrum; no hand deformities } \\
\text { and no micrognathia }\end{array}$ & $\begin{array}{l}\text { Persistent hypotonia with } \\
\text { developmental delay; } \\
\text { moderate learning difficulties } \\
\text { and severe sensorineural } \\
\text { deafness; height }<3 \text { rd } \\
\text { centile; normal ovarian } \\
\text { function }\end{array}$ \\
\hline $\begin{array}{l}\text { Patient } 2 \\
\text { (female; } \\
\text { sibling of } \\
\text { patient 1) }\end{array}$ & 1991 & $\begin{array}{l}\text { No clinical } \\
\text { illness (treated } \\
\text { from birth) }\end{array}$ & & $\begin{array}{l}\text { Cultured amniocytes: } \\
<5 \% \text { of controls }\end{array}$ & Not dysmorphic & $\begin{array}{l}\text { Moderate learning disability; } \\
\text { short stature; no } \\
\text { sensorineural deafness }\end{array}$ \\
\hline \multicolumn{7}{|l|}{ Pedigree B } \\
\hline $\begin{array}{l}\text { Patient } 3 \\
\quad \text { (female) }\end{array}$ & 1984 & $\begin{array}{l}\text { Poor feeding, } \\
\text { irritability, } \\
\text { jaundice, } \\
\text { hepatomegaly, } \\
\text { cataracts }\end{array}$ & $\begin{array}{l}\text { Raised liver } \\
\text { transaminases; raised } \\
\text { blood methionine; RBC } \\
\text { gal-1-P } 1738 \mu \mathrm{g} / \mathrm{ml} \\
\text { packed cells (normal } \\
<10 \text { ) }\end{array}$ & $\begin{array}{l}\mathrm{RBC} \text { and cultured skin } \\
\text { fibroblasts: undetectable }\end{array}$ & $\begin{array}{l}\text { Ligamentous laxity, } \\
\text { micrognathia, posteriorly rotated } \\
\text { ears, persistent femoral } \\
\text { anteversion, internal tibial } \\
\text { torsion, short stature (with } \\
\text { normal bone age) }\end{array}$ & $\begin{array}{l}\text { Severe sensorineural hearing } \\
\text { loss; moderate learning } \\
\text { difficulties; normal pubertal } \\
\text { development }\end{array}$ \\
\hline $\begin{array}{l}\text { Patient } 4 \\
\quad \text { (male; sibling } \\
\text { of patient } 3 \text { ) }\end{array}$ & 1985 & $\begin{array}{l}\text { Hypotonia, } \\
\text { poor feeding }\end{array}$ & $\begin{array}{l}\mathrm{RBC} \text { gal-1-P } 443 \mu \mathrm{g} / \mathrm{ml} \\
\text { packed cells; abnormal } \\
\text { serum transferrins }\end{array}$ & RBC: undetectable & $\begin{array}{l}\text { Micrognathia, high palate, } \\
\text { pigeon chest, flexion deformities } \\
\text { of the proximal and middle } \\
\text { third, fourth, and fifth fingers, } \\
\text { dislocatable left hip, positional } \\
\text { talipes and joint laxity, short } \\
\text { stature }\end{array}$ & $\begin{array}{l}\text { Tracheostomy for upper } \\
\text { airways obstruction at } 3 \\
\text { months; no sensorineural } \\
\text { deafness; poor feeding, } \\
\text { moderate developmental } \\
\text { delay with more profound } \\
\text { delayed gross motor skills }\end{array}$ \\
\hline $\begin{array}{l}\text { Patient } 5 \\
\text { (female; } \\
\text { cousin of } \\
\text { patients } 3 \\
\text { and } 4 \text { ) }\end{array}$ & 1994 & Hypotonia & $\begin{array}{l}\mathrm{RBC} \text { gal-1-P } 263 \mu \mathrm{g} / \mathrm{ml} \\
\text { packed cells; abnormal } \\
\text { serum transferrins }\end{array}$ & $\begin{array}{l}\text { RBC: } 0.090 \mu \mathrm{mol} / \mathrm{ml} \\
\text { packed cells } / \mathrm{h} \text { (controls, } \\
0.75-3.05)\end{array}$ & $\begin{array}{l}\text { Micrognathia, contractures of } \\
\text { the proximal interphalangeal } \\
\text { joints of her third, fourth, and } \\
\text { fifth fingers and toes, chest } \\
\text { deformity, poor tone, thickened } \\
\text { gums, short stature }\end{array}$ & $\begin{array}{l}\text { Severe sensorineural } \\
\text { deafness; global } \\
\text { developmental delay }\end{array}$ \\
\hline
\end{tabular}


withdrawing lactose from their diet. The other patients were diagnosed and commenced treatment before they developed noticeable illness. However, hypotonia has been a consistent finding in the newborn period in all the children and has persisted throughout infancy and into childhood despite treatment. Patients $1,3,4$, and 5 are dysmorphic (table 1 ).

In patients 4 and 5, we analysed serum transferrin by immunofixation and Coomassie brilliant blue staining following isoelectric focusing ( $\mathrm{pH}$ range, $4.0-6.0$ ). ${ }^{4}$ The pattern was abnormal at diagnosis but became normal within a few days in parallel with the fall in the concentrations of galactose-1-phosphate after the start of treatment. The abnormal pattern was identical to that seen in patients with type 1 carbohydrate deficient glycoprotein syndrome, with apparent increased concentrations of disialotransferrins and asialotransferrins.

All patients are short, despite satisfactory intrauterine growth. An arginine stimulation test produced a normal increase in growth hormone in patient 3. Thyroid function was normal in all patients. All have developmental delay and learning difficulties. Patients 1, 3, and 5 have sensorineural deafness, but not patients 2 and 4 . In contrast to classic galactosaemia, the two older female patients are showing normal pubertal development with appropriate follicle stimulating hormone (FSH), luteinising hormone (LH), and oestradiol values. Red blood cell gal-1-P concentrations have remained raised in the children but are lower than those seen in patients with classic galactosaemia while on treatment.

\section{Discussion}

Generalised GALE deficiency appears to be an exceptionally rare disorder. We are unaware of any other patients, although one patient reported initially to have this disorder was later confirmed as having GALT deficiency rather than epimerase deficiency. ${ }^{56}$ Both the families described here are highly consanguineous with first cousin marriages over many generations. In such families there may be more than one recessive disorder affecting individual members. Consequently, it is difficult to determine which features are caused by epimerase deficiency. For example in pedigree B, a further cousin, who did not have epimerase deficiency, had some dysmorphic features similar to patients 4 and 5 . The only consistent findings are failure to thrive with a very poor growth rate and learning difficulties.

Treatment for children with generalised GALE deficiency, as with GALT deficiency, is by restriction of dietary galactose. Galactose is an essential component of galactoproteins and galactolipids. In GALT deficiency there is considerable endogenous production of galactose and production of UDP-galactose by reversal of the pyrophosphorylase pathway. ${ }^{7}$ Theoretically, in generalised GALE deficiency, no such endogenous production of galactose is possible, with a resulting deficiency in galactolipid and galactoprotein production. Abnormal forms of the low density lipoprotein receptor, a glycoprotein, are synthesised by mutant ham- ster cells with a complete deficiency of GALE activity. However, fibroblasts from patient 1 have been shown to synthesise receptors of normal size and activity, suggesting that glycoprotein production is sufficient, presumably as a result of some residual GALE activity in the liver. ${ }^{8}$ Therefore, it might be unnecessary to provide patients with any dietary galactose. All our patients have been treated with a galactose restricted diet with a small amount of lactose added to allow the production of essential glycoproteins and glycolipids. The additional lactose has been discontinued in patients 1 and 2 without any obvious detrimental effect.

The abnormalities on transferrin isoelectric focusing also suggest underlying defects in glycosylation, which are corrected by dietary treatment. Whether this is a result of increased concentrations of galactose-1-phosphate or UDP-galactose, or some other mechanism, is not clear at this stage. Similar cathodal shifts in transferrins have been observed in untreated patients with classic galactosaemia as well as hereditary fructose intolerance, and evidence suggests that these secondary changes may reflect inhibition of key enzymes involved with $N$-glycosylation. ${ }^{9}$

Recently, the human GALE gene has been cloned and the full length cDNA characterised..$^{10}$ Mutations responsible for the peripheral form of GALE deficiency have been reported..$^{11}$ Mutation analysis has been undertaken recently in patients 1,4 , and 5 . All three children were found to be homozygous for the same mutation (V94M), the product of which had severely impaired GALE catalytic activity in a yeast expression system. ${ }^{12}$ This finding suggests that the two families are in fact related.

We conclude that generalised GALE deficiency is a serious disorder associated with life threatening illness in patients who ingest considerable quantities of galactose. As in GALT deficiency, treatment with a galactose restricted diet reverses this aspect of the disease but does not prevent the long term complications, primarily growth retardation and developmental delay. In view of the very small number of patients described with this condition and the fact that they are from highly consanguineous families, we cannot be certain which other features, such as the dysmorphism, are attributable to GALE deficiency.

1 Holton JB, Gillett MG, MacFaul R, Young R. Galactosaemia: a new severe variant due to uridine diphosphate mia: a new severe variant due to uridine diphosphate 1981;56:885-7.

2 Henderson MJ, Holton JB, MacFaul R. Further observations in a case of uridine diphosphate galactose-4pimerase deficiency with a severe clinical presentation. $\mathcal{F}$ nherit Metab Dis 1983;6:17-20.

3 Sardharwalla IB, Wraith JE, Bridge C, Fowler B, Roberts SA. A patient with severe type of epimerase deficiency galactosaemia. $\mathcal{F}$ Inherit Metab Dis 1988;11(suppl 2):24951

4 Stibler H, Jaeken J, Kristiansson B. Biochemical characteristics and diagnosis of the carbohydrate-deficient glycoprotein syndrome. Acta Paediatr Scand 1991;375:21-31.

5 Garibaldi LR, Canini S, Superti-Furga A, et al. Galactosemia caused by generalized uridine diphosphate galactose4-epimerase deficiency [published erratum appears in $\mathcal{f}$ 4-epimerase deficiency [published erratum appears
Pediatr 1986;109:1074]. F Pediatr 1983;103:927-30.

6 Garibaldi L, Superti-Furga A, Borrone C. Galactosemia caused by generalized uridine diphosphate galactose-4epimerase deficiency [letter]. F Pediatr 1986;109:1074-5. 
7 Berry GT, Nissim I, Lin Z, Mazur AT, Gibson JB, Segal S. Endogenous synthesis of galactose in normal men and patients with hereditary galactosaemia. Lancet 1995;346: 1073-4.

8 Kingsley DM, Krieger M, Holton JB. Structure and function of low-density-lipoprotein receptors in epimerasedeficient galactosemia [letter]. $N$ Engl f Med 1986;314: 1257-8.

9 Jaeken J, Pirard M, Adamowicz M, Pronicka E, Van Schaftingen $\mathrm{E}$. Inhibition of phosphomannose isomerase by fructose 1-phosphate: an explanation for defective $\mathrm{N}$-glycosylation in hereditary fructose intolerance. Pediat Res 1996;40:764-6.
10 Daude N, Gallaher TK, Zeschnigk M, et al. Molecular cloning, characterization, and mapping of a full-length cDNA P-galactose 4'-epimerase. Biochem Mol Med 1995;56:1-7.

11 Maceratesi P, Daude N, Dallapiccola B, et al. Human UDPgalactose 4' epimerase (GALE) gene and identification of five missense mutations in patients with epimerasedeficiency galactosemia. Mol Genet Metab 1998;63:26-30.

12 Wohlers TM, Christacos NC, Harreman MT, FridovichKiel JL. Identification and characterization of a mutation in the human UDP-galactose-4-epimerase gene associated with generalized epimerase-deficiency galactosaemia. Am $\mathcal{F}$
Hum Genet. [In press.]

\section{Xylitol and acute otitis media}

Xylitol is used as an artificial sweetener and its use prevents dental caries, not only by replacing sucrose but also by inhibiting Streptococcus mutans. Paediatricians in Finland found that xylitol also inhibited the growth of pneumococci, and in a $1996 \mathrm{BMF}$ paper they showed that xylitol chewing gum reduced the occurrence of otitis media in children old enough to chew it. Now they have compared xylitol syrup, lozenges, and gum with placebos in younger children (Matti Uhari and colleagues. Pediatrics 1998;102:879-84).

The study included 857 healthy children aged from 7 months to 7 years attending day care centres. Those old enough to chew safely were randomly assigned to xylitol or placebo, chewing gum or lozenges. The younger ones were randomised to xylitol or placebo syrup. Over a trial period of three months the incidence of acute otitis media was reduced by $30 \%$ with xylitol syrup, by $40 \%$ with chewing gum, and by $20 \%$ with lozenges, compared with the placebo groups. There were similar reductions in the use of antibiotics.

Commentators (Ibid: 971-2 and 974-5) caution against rushing into the widespread administration of xylitol to children. Their reasons are both theoretical (the dose needed for young children could cause gastrointestinal upset, its safety is not established, and the long term effectiveness is uncertain) and pragmatic (the minimal effective dose is not known (it was given five times daily in the trial) and there are no suitable preparations available in the USA). The way in which xylitol produces this effect is far from clear. An antipneumococcal action does not seem to be a full explanation.

It seems unlikely that xylitol treatment of all children will be either practicable or desirable but further work could show it to be beneficial for those with recurrent acute otitis media. The associated decrease in antibiotic use is attractive in view of present concerns about antibiotic resistance. 